\title{
Thread Device
}

National Cancer Institute

\section{Source}

National Cancer Institute. Thread Device. NCI Thesaurus. Code C50323.

A fine cord typically used for sewing. 